The Third Pole: Journal of Geography

Vol. 18 - 19: 21-34, 2019

DOI: https://doi.org/10.3126/ttp.v18i0.27991

Department of Geography Education,

Central Department of Education, T.U., Kathmandu, Nepal

\title{
SOCIO-ECONOMIC CONSEQUENCES OF AGRICULTURAL LAND USE CHANGE IN TARAI OF NAWALPARASI DISTRICT
}

\begin{abstract}
Bhola Nath Dhakal, PhD ${ }^{1}$
Abstract

Changes in agricultural land use have a profound impact on the personal, family and social lives of people living in rural as well as semi-urban communities. The main objective of this paper is to explore socio-economic consequences of agricultural land use change during 2005/06 to 2015/16 in Nawalparasi District. This paper is based on collected primary data through household questionnaire survey, Focus Group Discussion (FGD), Key Informant Interview (KII) and field observation methods. Secondary sources of data through published and unpublished government documents, topographic and cadastral maps, and satellite images have been used in this study. Loss of cropping land and decreasing productivity, land fragmentation and increasing cost of inputs, changes in food security, increasing the land value, housing and rental cost, change in occupation, sources of income and expenditure and implementation of intensification and diversification strategies are the major consequences found in the study sites.
\end{abstract}

Key words: Agricultural land use, socio-economic impacts, productivity, food security intensification.

\section{Introduction}

Agriculture is a major sector in the economy of Nepal. The sustainable use of agricultural land is therefore essential to economic growth, human well-being, social equity, and ecosystem services (MoAD, 2015). It is important to understand the different land uses being undertaken in the study area, and the diversity of ways in which they have been changing in recent years when analyzing the impacts of agricultural land use change.

1 Dr. Dhakal is a Lecturer, Department of Geography, Ratna Rajya Campus, Tribhuvan University, Kathmandu, Email: dhakalbn@gmail.com 
Agricultural land use change is not a simple matter of a shift in the area of land used for a particular commodity; it involves a range of changes including changes in what is produced on land, how it is produced, and the intensity of production, amongst others (Lubowski et al., 2006). Socioeconomic characteristics have a fundamental role in determining the status of food security and household's income (Ajani et al., 2006; Babatunde et al., 2007). It has been claimed that the general household characteristics of farming communities who live in the same region do not differ much from each other, mainly because agriculture remains the backbone of the rural economy and of the primary means of households for securing their livelihoods (Kalonga \& Kulindwa, 2017).

The conversion of farmland to urban development reduces the amount of land available for food, reduces the amount of open space and environmental amenities for local residents and reduces the significance of farmland for the economic survival of local agricultural economies (Wu, 2008). Change in agricultural land and suburbanization intensifies income segregation and economic disparities among communities and raise housing prices, making housing less affordable to middle and low-income households (Cho, Wu, \& Boggess, 2003).

Different consequences of agricultural land use change have been noticed due to increasing in the area and use intensity of land; land degradation reduced and intensification caused an input cost reduction, increased yield levels and shifting crop production towards high-value commodities, improved households' economy, reduced poverty, changed in agricultural landscapes, reduced the youth out-migration (Miheretu \& Yimer, 2017; Feike et al., 2014; and Wood et al., 2004). Decreasing the number of farms and use of inputs has declined in agricultural activity and population dynamics, loss in production and income sources (Assefa \& Bork, 2014; Olaniyi et al., 2013; and Gulgun et al., 2009). Due to farm fragmentation and decreased in average farm size has resulted to increase input cost (Tanrivermis, 2003). Intensification of crop land has increased in productivity and supported in food security, as well as resulted positive changes in wealth and social status (Virgo \& Subba, 1994; Poudel, 2002; and Dahal et al., 2009). The decreasing in agricultural land has caused increasing food shortage and declining livelihood options (Khanal \& Watanabe, 2006) and caused negative impacts on socioeconomic and ecological environment (Paudel et al., 2014). However, identifying the impacts of agricultural land use change is challenging. There are a lot of consequences of agricultural land use changes. The main objective of this study was to explore socio-economic consequences of agricultural land use change in Nawalparasi District. 


\section{Methods and material}

Data Source: The paper has used both primary and secondary data. Primary data has been generated from household survey. All together 93 households (31 households from each site) were surveyed with semi-structured questionnaire. Information on socioeconomic consequences due to the agricultural land use change was collected through face to face household questionnaire survey. Focus Group Discussion and Key Informant Interviews were conducted for firsthand knowledge about the result of community and agricultural activities. Similarly, the available secondary data and reports such as Village Development Committee (VDC) profiles, annual reports of District Agriculture Development Office (DADO), topographic and cadastral maps and satellite images has been used to create secondary data. Both qualitative and quantitative techniques have been used for the data generation and compilation.

Study Area: This study area is located in Nawalparasi district (West of BardaghatSusta), Province number 5 of Nepal. Ecologically, the area lies in the Tarai region of western Nepal. It is bordering Palpa district in the north, Nawalparasi (East of Bardaghat-Susta) and Chitwan districts in the east, Bihar state of India in the south, and Rupandehi district in the west. During the field work, the district was divided into 56 VDCs, 7 Municipalities, 15 Ilakas and 6 Constituencies (MoFALD, 2015). On the basis of biophysical and socio-economic characteristics of the study area three wards (one from each) from Jahada (Ward number 3), Palhi (Ward number 9) and Ramnagar (Ward number 5) Village Development Committees were randomly selected for detail study.

According to new structure, the study area, ward number 3 of Jahada VDC lies in ward number 13 of Bardaghat Municipality, ward number 9 of Palhi VDC lies in ward number 4 of Palhi Nandan Rural Municipality and ward number 5 of Ramnagar VDC lies in ward number 11 of Sunwal Municipality. Jahada VDC is located in the middle part of the district and extends from $83^{\circ} 44^{\prime} 17^{\prime \prime}$ to $83^{\circ} 46^{\prime} 51^{\prime \prime}$ East longitude and $27^{\circ} 28^{\prime} 18^{\prime \prime}$ to $27^{\circ} 31^{\prime} 23^{\prime \prime}$ North latitude within the surface area of $14.34 \mathrm{sq} \mathrm{km}$. Palhi VDC is located in southern part of the district and extends from $83^{\circ} 39^{\prime} 14^{\prime \prime}$ to $83^{\circ} 40^{\prime} 39^{\prime \prime}$ East longitude and $27^{\circ} 27^{\prime} 38^{\prime \prime}$ to $27^{\circ} 30^{\prime} 04^{\prime \prime}$ North latitude within the surface area of $6.42 \mathrm{sq} \mathrm{km}$. Ramnagar is situated between Chure hill in northern side and plain land in southern part. It extends from $83^{\circ} 40^{\prime} 04^{\prime \prime}$ to $83^{\circ} 43^{\prime} 57^{\prime \prime}$ east longitude and $27^{\circ} 32^{\prime} 46^{\prime \prime}$ to $27^{\circ} 37^{\prime} 12^{\prime \prime}$ north latitude within the surface area of $29.47 \mathrm{sq} \mathrm{km}$ (Figure 1).

The total population in Jahada has 1116 residing within households of 246 and population density of 467 person/sq $\mathrm{km}$. The total population in Palhi has 484 residing within households of 74 and population density of 397 person/sq km. Similarly, there are 1851 
population in Ramnagar who are residing within 406 households and population density of 302 persons $/ \mathrm{sq} \mathrm{km}$.

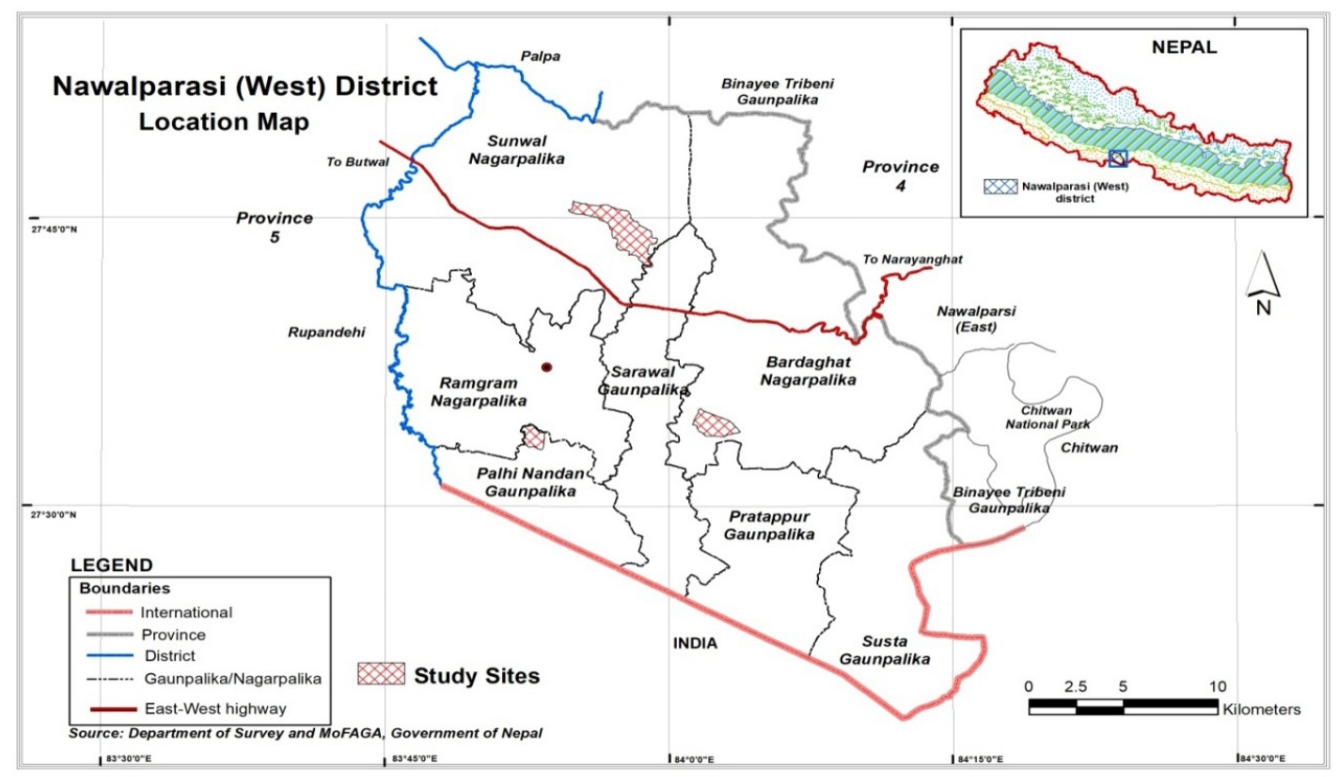

Figure 1: Location of Study Sites

\section{Results and Discussions}

This paper identified some of the socioeconomic consequences regarding to agricultural land use changes in the study area. They can be classified into two major groups: positive and negative. They are discussed as follows:

\section{Positive consequences}

Changes in food security: Food security is the important social determinant of the livelihood. The shift from subsistence cereal farming to an intensive vegetable-based farming, livestock raising, bee-keeping and fish farming like cash earning farming system has significantly improved the food security in study area. The vegetables growers have increased their income from farm by selling vegetables in nearby markets and thus, from the income, they can buy food and other household items from the market. Thus, agricultural intensification enhanced the quantity of food production, improvements in food security and farmers are also able to consume more nutritious food in terms of more green vegetables in their diet. 
Table 1 shows that 2.5 percent of respondents are sustaining for up to 6 months from their own land agricultural production in Jahada area. It was 3.4 percent before 10 years. They need to buy cereal food like rice, wheat flour, maize etc. for the rest of food deficiency period. Whereas 58.1 percent of total respondents informed that they produce food to meet their family, needs it was 53.3 percent before 10 years in Jahada. Further, it is found that 23 percent of total respondents mentioned that they produce surplus food from their land and able to supply in the market for cash return or store for next year. It was 30 percent of total households before 10 years in Jahada. It is found that 6.5 percent of respondents are sustaining for up to 6 months from their own land agricultural production in Palhi. It was 10.3 percent before 10 years. Further, it is found that 38.1 percent of total respondents mentioned that they produce surplus food from their land and able to supply in the market for cash return or store for the next year. It was 42.1 percent of total households before 10 years in Palhi. Further, it is reported that 3.4 percent of respondents are sustaining for up to 6 months from their own land agricultural production in Ramnagar. It was 7.5 percent before 10 years. Similarly, it is found that 21.5 percent of total respondents mentioned that they produce surplus food from their land and able to supply in the market for cash return or store for next year. It was 54.2 percent of total households before 10 years in Ramnagar. The respondents from FGD and KII also reported that the food security condition of the study area has improved now than earlier. So, it is concluded that the production and consumption status is getting improved during the study period through adopting different alternatives like intensification of land and diversification of crops in the study area.

Table 1: Food security status (households in percent)

\begin{tabular}{l|c|c|c|c|c|c}
\hline \multirow{2}{*}{ Sufficiency status } & \multicolumn{2}{|c|}{ Jahada } & \multicolumn{2}{c|}{ Palhi } & \multicolumn{2}{c}{ Ramnagar } \\
\cline { 2 - 7 } & $2005 / 06$ & $2015 / 16$ & $2005 / 06$ & $2015 / 16$ & $2005 / 06$ & $2015 / 16$ \\
\hline 6 months & 3.4 & 2.5 & 10.3 & 6.5 & 7.5 & 3.4 \\
9 months & 13.3 & 16.4 & 11.9 & 17.9 & 14.2 & 11.2 \\
12 months & 53.3 & 58.1 & 35.7 & 37.6 & 54.2 & 63.9 \\
Surplus & 30.0 & 23.0 & 42.1 & 38.1 & 24.1 & 21.5 \\
\hline
\end{tabular}

Source: Field Survey, 2015/16

Increase in land values and housing/rental cost: It is found that there is high scarcity of land for crop production due to the result of cropping land changed into urban/ built up land in study area. With the development of infrastructure, the access to the market and other service centers has become easier than past. Altogether 66.5 percent of respondents reported that there is increasing in land value by 5-6 times more than past 10 years for cropping land whereas up to 10 times increasing in residential sites 
and more and uncontrolled land value in business areas. During the field survey, it is also reported by 37.2 percent of respondents that there is increasing in housing or rental cost by 3-4 times than past few years. Due to the in-migration and increased population density in agricultural land, there is decreasing cropping land as well as being scarcity of space for the construction of buildings in study area.

Changes in occupation, sources of income and expenditure: The shift of occupation from farming to non-farming activities is a recent phenomenon in Nepal. The study examined how changes in land use affected the number of people working in traditional agricultural industries. This is an important measure of social change in regions which have a history of high reliance on traditional agriculture as an employment base. Economic forces such as government payments, off-farm employment, land size, land ownership, types of farm enterprises, and rural-urban location of households are the factors contributing to farm exit.

There has been series of transitions not only in demography and mobility but also in occupation, education, income and expenditure patterns and lifestyle over time. Such individual transitions are mutually interdependent and have significant impact of agricultural land use change. Agriculture has remained a major economic activity since historical time in the study area; however, people have adopted different economic activities in the changing government policies, social and spatial context in the study area. Due to the loss in crop land and production, farmer started to adopt another sources of income from different sources. Household survey shows that the average number of livestock population per household has been increasing in the study area. In addition, dairy farming has been developing after the improvement in the infrastructure and access to market centers. It shows that more than 62.1 percent of people were involving in crop production during the 2005/06 period whereas now only 53.7 percent of total populations are involving in crop production only. It is found that 23.8 percent of populations are involving in livestock farming with crop farming during 2015/16 which was only 7.3 percent during 2005/06. Similarly, 7.5 percent of respondents are involving in bee-keeping, 6.4 percent of total respondents in study area doing fish farming and 2.1 percent involving in poultry farming with cropping. In addition, 14.1 percent human resources of total population were migrated to abroad countries from 51.6 percent of surveyed households in the study area during the study period (Dhakal, 2019).

There are different sources of income in study area for their livelihood beyond the agricultural activities. In the absence of recorded data in the past on household income and its sources, it is not possible to quantify the change in the proportional 
contribution of different sectors in household income. However, on the basis of qualitative information on livelihood pattern in the past discussed above, it is clear that there has been a shift in the contribution in the household income from crop farming and livestock to remittances, pensions, services and business in the study area in recent years. Since, the value of marginal productivity of labour is lower for all the crops grown in the study area than the average wage rate in other sectors such as construction work and service inside the country and it is extremely lower as compared to the earning outside the country. There is a shift of labour participation from agriculture to other sectors. Because of such a shift in labour from agriculture to other sectors, there is shortage of agricultural labour. It is found that dominant contribution in sources of income of the farmers is contributed from remittance in the study area. It is also remarkable in national economy. It is reported that 52.3 percent of total income contributed from remittances. In addition, other sources like pension (13.3 percent), sell of surplus crop product ( 8.3 percent), from services 7.8 percent, business ( 4.5 percent), and livestock ( 4.4 percent) and rest parts contributed by sell of vegetables, wages and others. So, the income from crop production (only 8.3 percent) is very low comparison with other sources of income (Dhakal, 2019). Furthermore, it is found that total annual expenditure of farm households has also changed in the study sites due to change in agricultural land use. Farmers have invested more capital in readymade food items which are imported from outside such as flattened rice, noodles, bread and biscuits. It accounts for 27.6 percent of the total annual household expenditure in the study area.

Household survey reveals that rural to urban migration in search of jobs, social services such as education and health and other urban amenity increased drastically after 2000s. The opening of employment opportunities in foreign countries especially in Gulf countries, fixation of ownership right and improvement in accessibility are some of the reasons for the change in agricultural land. Respondents informed that most of the people working in foreign job have been given less priority in crop production even to live in rural areas. They are interested to migrate in urban areas and buy readymade foods. They have started to invest on housing, clothing and education of the children, medicine, social ceremonies, and transportation.

Implementation of intensification and diversification strategies: Intensification and diversification are the important strategies in agricultural development and uplifting economic conditions of farmers. Farmers have implemented intensification and diversification practices in study area due to the changes in agricultural land use and challenging to feed for growing population. Like the global concept of intensification, the types of crops that farmers are cultivating in the study area reflect the market- 
oriented and diversified nature of intensified cropping. It is found that more than 88 percent of farmers are adopting intensification practice in the study area. Similarly, farmers supported the concept of diversification of farming systems as a pro-active solution to the socio-economic problems encountered by them.

The study found that farmers have practiced to cultivate many crops than the past to increase production even in the same area of land. Further, respondents informed that 16.1 percent of agricultural land holdings used to grow three and more crops during agriculture year in Jahada, which was only 11.8 percent before 10 years. Similarly, 48.4 percent of holdings are reported to grow three and more crops during agriculture year in Ramnagar now which was only 13.6 percent during 2005/06. Whereas 16.5 percent of land holdings are reported to grow three and more crops during agriculture year in Palhi, which was only 3.7 percent area of total cultivated land during 2005/06. The participants during FGD and KII also further reported that farmers have tried to explore new varieties of seeds from neighboring districts and applied within two to three years' interval. Sometimes they used to repeat their own local seeds. They depended on the seasonal irrigation facilities as well as other modern inputs like machineries, organic and chemical fertilizers, pesticides etc. Altogether 28.4 percent of total respondents within 69.7 percent of identified parcel area $(60.4 \%$ in Jahada, $81.8 \%$ in Palhi and $68.2 \%$ in Ramnagar) have used intensive farming in the parcels close to residence/ house than some farther location. Similarly, there are 19.2 percent (13.5\% in Jahada, $14.3 \%$ in Palhi and $27.5 \%$ in Ramnagar) of the total crop land in the study area has been used for crop diversification (Dhakal, 2019). That is, they have been changing their crops, usually potato, vegetables, oilseeds and pulses with wheat in previous wheat monoculture area in the study sites.

\section{Negative consequences}

Loss of cropping land and decreasing productivity: Decline in the area and level of production has found one of the major consequences in the study area due to the agricultural land use change. Agricultural land has decreased by 25.6 percent in the study area during the period of 10 years. Further, it is noticed that paddy cultivated area has decreased by 7.7 percent and production has decreased by 25.2 percent within study period (Table 2). Rice is the main staple food of Nepalese people. So it is challenging to produce more paddies as well as other crops to recover the deficiency trend on production since 10 years. Similarly, production of other crops also has been decreased within same study period which has directly effect on economic condition of respondents and forced to do alternate activities in the study area. 
It is found that the area under potato cultivate on has increased but the production has decreased in Jahada and Ramnagar area. It was reported by the respondents that due to the effect of harmful weed (like patera, dadhuwa and gabaro) in (2014/15) damaged the crop in most of land in Jahada, Ramnagar and surrounding area. Similarly, it is also found that area under paddy and oilseeds has increased during the study period but production has decreased in Palhi area due to the problem of irrigation (insufficiency on volume of water in canal) as reported by respondents. Whereas production of most of the crops have not increased with the proportion of area increased in the study sites due to the lack of proper attention on agriculture.

The participants during FGD and KII also reported that due to the uncertainty of weather, unavailability of sufficient water in canal and ditches, effect of diseases were the main causes in loss of production of crops like paddy, wheat, maize and oilseeds in the study area. They also added that the economic condition of the local residents of the study area has been affected due to the loss in production which forced to search alternate activities to substitute on their economy.

Table 2: Change in Cropping area and Production (in percent)

\begin{tabular}{l|c|c|c|c|c|c|c|c}
\hline \multirow{2}{*}{ Crops } & \multicolumn{2}{|c|}{ Jahada } & \multicolumn{2}{c|}{ Palhi } & \multicolumn{2}{c|}{ Ramnagar } & \multicolumn{2}{c}{ Total } \\
\cline { 2 - 9 } & Area & Production & Area & Production & Area & Production & Area & Production \\
\hline Paddy & -24.1 & -26.3 & 0.3 & -28.8 & -18.7 & -4.9 & -7.7 & -25.2 \\
Maize & 1.6 & 52.2 & -0.1 & -20.0 & 13.9 & 3.9 & 4.9 & 7.3 \\
Wheat & 11.1 & 48.8 & 13.9 & -0.3 & 2.2 & 26.2 & 10.6 & 8.4 \\
Potato & 2.6 & -43.0 & -0.4 & -54.7 & 0.4 & 2.5 & 0.9 & -44.0 \\
Vegetables & 0.2 & 33.3 & 0.7 & 14.2 & 4.0 & 7.4 & 2.3 & 11.8 \\
Oilseeds & -9.3 & -51.9 & 1.2 & -26.2 & 9.3 & 14.3 & 0.5 & -32.6 \\
Pulses & -1.3 & -57.7 & -0.9 & -20.5 & -1.5 & -34.2 & -0.9 & -35.0 \\
\hline
\end{tabular}

Source: Field Survey, 2015/16

Land fragmentation and increasing cost of inputs: This study found that the production cost has increased due to the increasing trend of fragmentation of cropping land in the study area. Fragmentation is a common characteristic of agricultural land in Nepal. Several reasons have noticed for land fragmentation including growth rate of population, infrastructure development, legal provision and land tenure system in the study area. Land fragmentation has many consequences in agriculture development. The large numbers of household $(78.5 \%)$ has reported that the fragmentation led to increasing time and cost of input such as labour, fertilizers and pesticides. In the absence 
of it, productivity has been declined. Similarly 52.7 percent of households have reported productivity of crops has decreased due to having increased numbers of small patches of lands and 34.4 percent households reported that it has the problem of mechanization due to the small size and scattered land patches hence the opportunity of increasing the benefit from agriculture has declined.

Table 3: Distance from house to plot (in meters)

\begin{tabular}{c|c|c|c|c|c}
\hline $\begin{array}{c}\text { Number of } \\
\text { parcels }\end{array}$ & $\begin{array}{c}\text { Households } \\
(\%)\end{array}$ & $\begin{array}{c}\text { Average size of } \\
\text { parcels (ha) }\end{array}$ & $\begin{array}{c}\text { Minimum } \\
\text { distance }\end{array}$ & $\begin{array}{c}\text { Maximum } \\
\text { distance }\end{array}$ & $\begin{array}{c}\text { Average } \\
\text { distance }\end{array}$ \\
\hline 2 & 26.7 & 0.6507 & 160 & 1324 & 688 \\
3 to 4 & 53.3 & 0.4859 & 51 & 3396 & 798 \\
Above 4 & 20.0 & 0.4056 & 25 & 1610 & 636 \\
\hline
\end{tabular}

Source: Compiled from Field Survey, 2015/16

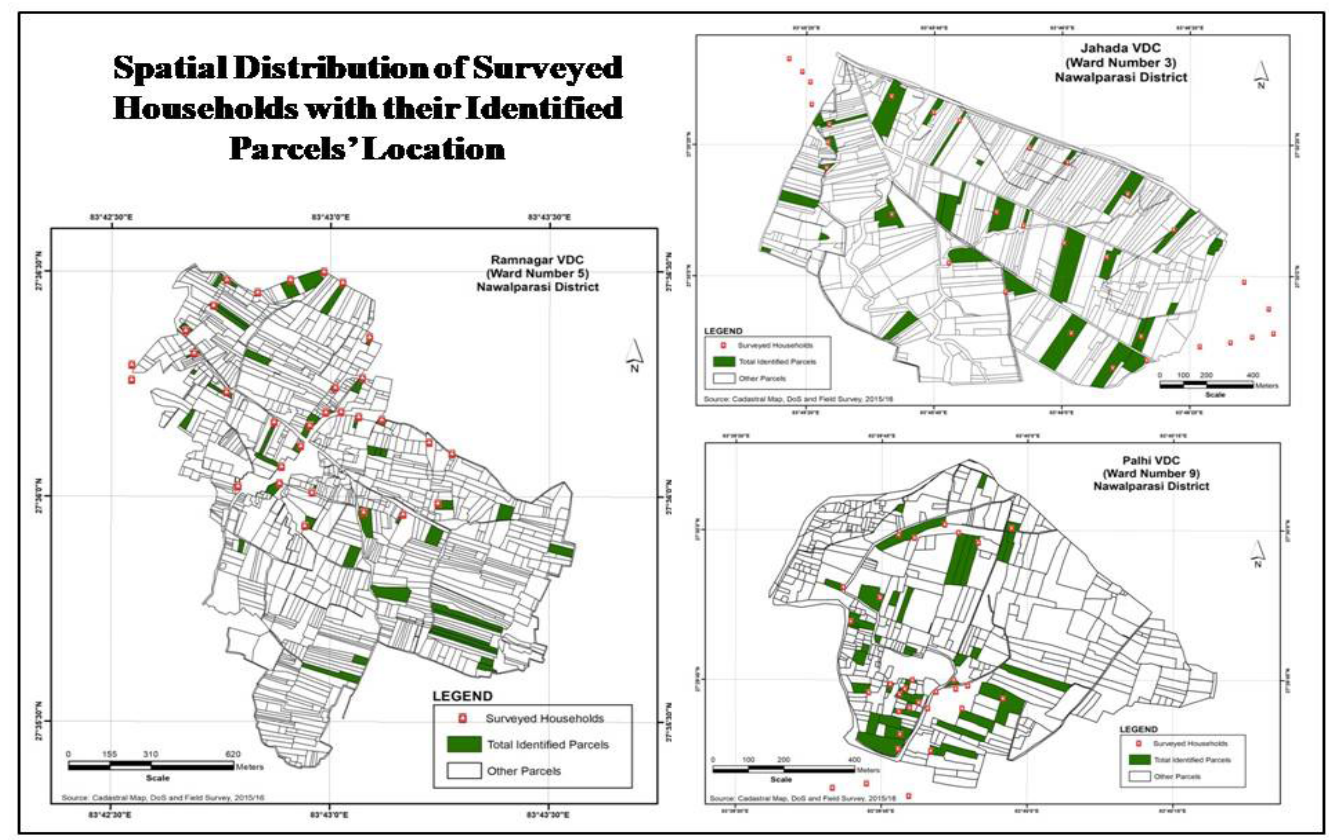

Figure 2: Distribution of Parcels in the Study Sites

Crop land fragmentation, plotting and construction of buildings have enhanced to the urbanization. This has become challenging for the sustainable development of 
agriculture in future. It is concluded that the input cost has increased in terms of use of labour force during the study period. During Focus Group discussion and KII, it is reported that the rate of land fragmentation in the study area has been increasing and also argued that due the increasing trend of land fragmentation and decreasing trend of cultivated parcel size as well as distance to the farm from house caused the high input cost.

The study found that most of houses and crop land parcels are located separately from each other (Figure 2) and confirmed the result as reported by respondents in the field during the survey. It is found that most of the respondents (53.3 percent) have 3 to 4 parcels with average size of 0.4859 hectare and within the average distance of 798 meters from their house (Table 3).

\section{Conclusion}

Agricultural land use change is a complex and dynamic process. Agricultural land has increased during 1958 to 1994 but it has decreased from 1994 to 2009 where area under crop land has decreased and has changed to other areas, particularly to built-up area in all study sites. Furthermore, there is a variation in pathways and magnitude of agricultural land use change in the study sites. It has changed agricultural land to built-up area by 18.6 percent in Jahada, by 31.5 percent in Palhi and by 10.9 percent in Ramnagar. With increasing number of households, agricultural land further fragmented and holding size further decreased. The overall landholding size owned by agricultural holding has decreased in study sites. Landholding size was 0.297 ha per capita in 2005/06 and decreased to 0.150 ha in 2015/16 in Jahada. Similarly, it has decreased from 0.325 ha to 0.189 ha in Palhi and it has also decreased from 0.098 ha to 0.066 ha in the same period in Ramnagar.

Change in agricultural land use has many socio-economic consequences ranging from access to variety of resources to the use of inputs to obtain the household needs. This study has found loss of cropping land and decreasing productivity, land fragmentation and increasing cost of inputs, changes in food security, increasing the land value, housing and rental cost, change in occupation, sources of income and expenditure and implementation of intensification and diversification strategies are the major consequences in the study sites. Agricultural land has decreased by 25.6 percent and production has decreased by 25.2 percent in the study area during the period of 10 years. The fragmentation led to increasing time and cost of input such as labour, fertilizers and pesticides. In the absence of it, productivity has been declined. Similarly farmers have faced the problem of mechanization due to the small 
size and scattered land patches hence the opportunity of increasing the benefit from agriculture has declined. Agricultural intensification and diversification enhanced the quantity of food production, improvements in food security. The occupation has shifted from farming to other off-farm activities including foreign employment. Most of the income supported from remittances. Farmers have invested more capital in readymade food items. Dominant of identified parcel area have used intensive farming and crop diversification in the parcels close to residence/house than some farther location.

\section{References}

Ajani, S. R., Adebukola, B. C. \& Oyindamola, Y. B. (2006). Measuring household food insecurity in selected local government areas of Lagos and Ibadan, Nigeria. Pakistan Journal of Nutrition, 5: 62-67.

Assefa, E., \& Bork, H. (2014). Dynamics and driving forces of agricultural landscapes in Southern Ethiopia: A case study of the Chencha and Arbaminch areas. Journal of Land Use Science, 11(3), 278-293. doi: 1080/1747X.2014.940613.

Babatunde, R. O., Omotesho, O. A. \& Sholotan, O. S. (2007). Socio-economic characteristics and food security status of farming households in Kwara State, North-Central Nigeria. Pakistan Journal of Nutrition, 6: 49-58.

Cho, S., Wu, J., \& Boggess, W. G. (2003). Measuring interactions among urbanization, land use regulations, and public finance. American Journal of Agricultural Economics, 85, 988-999.

Dahal, B. M., Nyborg, I., Sitaula, B. K., \& Bajracharya, R. M. (2009). Agricultural intensification: Food insecurity to income security in a mid-hill watershed of Nepal. International Journal of Agricultural Sustainability, 7(4), 249-260.

Dhakal, B. N. (2019). Agricultural land use change in Tarai of Nawalparasi district: A temporal and spatial analysis. (Unpublished doctoral dissertation). Tribhuvan University, Kathmandu, Nepal.

Feike, T., Mamitimin, Y., Li, L., \& Doluschitz, R. (2014). Development of agricultural land and water use and its driving forces along the Aksu and Tarim River, China. Environment Earth Science, doi: 10.1007/s12665-014-3108-x.

Gulgun, B., Yoruk, I., Turkyilmaz, B., Bolca, M., \& Gunes, A. (2009). Determination of the effects of temporal change in urban and agricultural land uses as seen in the 
Bhola Nath Dhakal / Socio-Economic Consequences of Agricultural Land ...

example of the town of Akhisar, using remote sensing techniques. Environment Monitoring Assessment, 150, 427-436.doi: 10.1007/s10661-008-0241-6

Kalonga, S. K. \& Kulindwa, K. A. (2017). Does forest certification enhance livelihood conditions? Empirical evidence from forest management in Kilwa District, Tanzania. Forest Policy and Economics, 74: 49-61.

Khanal, N. R., \& Watanabe, T. (2006).Abandonment of agricultural land and its consequences. Mountain Research and Development, 26(1), 32-40.

Lubowski, R. N., Bucholtz, S., Claassen, R., Roberts, M. J., Cooper, J. C., Gueorguieva, A., \& Johansson, R. (2006). Environmental effects of agricultural land use change: The role of economics and policy. Economic research report number 25.United States Department of Agriculture (USDA).http://www.ers.usda.gov

Miheretu, B. A., \& Yimer, A. A. (2017). Determinants of farmers' adoption of land management practices in Gelana sub watershed of Northern highlands of Ethiopia. Ecological Processes, 6, 19. doi:10.1186/s13717-017-0085-5

MoAD. (2015). Agriculture development strategy, 2015-2035. Kathmandu: Government of Nepal, Ministry of Agricultural Development.

MoFALD. (2015). Jilla, Nagarpalika tatha Gaunbikash Samitiharuko sanchhipta bibaran pustika (in Nepali), Kathmandu: Government of Nepal, Ministry of Federal Affairs and Local Development.

Olaniyi, A. O., Abdulla, A. M., Ramli, M. F., \& Sood, A. M. (2013). Agricultural land use in Malaysia: An historical overview and implications for food security. Bulgarian Journal of Agricultural Science, 19(1), 60-69.

Paudel, B., Acharya, B., Ghimire, R., Dahal, K. R., \& Bista, P. (2014). Adapting agriculture to climate change and variability in Chitwan: Long-term trends and farmers' perceptions. Agricultural Research, 3(2), 165-174.

Poudel, G. S. (2002). Coping with land scarcity: Farmers' changing land use and management practice in two mountain watersheds of Nepal. Norwegian Journal of Geography, 56, 21-31.

Tanrivermis, H. (2003). Agricultural land use change and sustainable use of land resources in the Mediterranean region of Turkey. Journal of Arid Environments, 54(3), 553-564. DOI: 10.1006/jare.2002.1078 
Virgo, K. J., \& Subba, K. J. (1994). Land use change between 1978 and 1990 in Dhankuta district, Koshi Hills, Eastern Nepal. Mountain Research and Development, 14(2), 159-170.

Wood, E. C., Tappana, G. G., \& Hadjb, A. (2004). Understanding the drivers of agricultural land use change in South-Central Senegal. Journal of Arid Environments, 59, 565-582.

Wu, J. (2008). Land use changes: Economic, social, and environmental impacts. CHOICES, 23(4), 6-10. 